\title{
O dilema fiscal: remendar ou reformar?"
}

\section{Fernando Rezende, Fabrício Oliveira e Erika Araujo (orgs.) Rio de Janeiro: Editora FGV, 2008.}

O livro intitulado O Dilema Fiscal: Remendar ou Reformar? dos autores Fernado Resende, Fabrício Oliveira e Erika Araujo, busca apresentar, de forma detalhada, as causas, conseqüências e possíveis soluções para o problema fiscal brasileiro. Os autores argumentam que a principal dificuldade de uma reforma fiscal abrangente não é promovê-la e sim disposição para implementá-la. Neste sentido, o livro busca orientar o leitor cronologicamente através das medidas adotadas ao longo do tempo pelos respectivos governantes do país.

Já na introdução é apresentado, o que os autores identificam como sendo o principal entrave ao crescimento do país, o caráter dual do sistema tributário brasileiro. Ou seja, após a implementação da Constituinte de 1988, com a elevada demanda por autonomia financeira pelos estados e municípios e, no campo dos direitos sociais, a diversificação das fontes de financiamento, tevese como conseqüência um sistema tributário dual. Neste sistema, o governo brasileiro tem basicamente duas fontes de financiamento: a própria tributação e o regime de financiamento da seguridade social. Com o crescimento das contribuições para a seguridade devido à reforma constitucio- 
nal, a qualidade da tributação se deteriora, reduzindo o compromisso de fortalecimento da federação. O pior do uso destas duas fontes de receita viria para o caso das contribuições: a) estas não são compartilhadas com estados e municípios, b) $80 \%$ de suas receitas são vinculadas a gastos com seguridade social (previdência, assistência e saúde) e c) não se preocupam em não causar distorções econômicas. $\mathrm{O}$ argumento dos autores baseia-se no fato de que as receitas federais com impostos foram reduzidas com a promoção da descentralização, e, no entanto, aumentou-se o compromisso financeiro sob a responsabilidade da União com o aumento dos benefícios ou direitos sociais previstos na nova Constituição.

Seguindo esta linha de raciocínio, os autores diagnosticam o que nomearam ser o efeito cremalheira que consiste em: cada aumento na arrecadação de contribuições sociais corresponde a outro aumento das despesas obrigatórias, o que pode ocasionar futuros aumentos da carga tributária novamente em decorrência do engessamento do orçamento e a perda de qualidade do sistema tributário. Desta forma, o elevado nível de despesas obrigatórias dificulta a promoção do ajuste fiscal via redução de gastos. Ao elevar a carga tributária, novos gastos seriam necessários $(80 \%$ das receitas geradas). A este fenômeno é atribuída a essência do dilema fiscal.

Os autores ainda sugerem que a questão federativa é de grande importância para a reforma fiscal. Os governadores e prefeitos podem reivindicar a mesma proposta de desvinculação de receitas que o governo federal o que pode provocar reação negativa dos setores que mais perderiam com esta medida (saúde e educação). Neste sentido, seria também necessário uniformizar o ICMS e eliminar distorções causadas por diferentes alíquotas interestaduais.

No sentido de proporcionar uma solução para o problema fiscal, os autores apontam, como exemplo, o Plano Real, que somente eliminou a inflação no Brasil após implementação de uma política ortodoxa e abrangente que não se limitava a medidas de fôlego curto como confiscos e congelamento de preços. Ou seja, os autores defendem uma reforma abrangente e argumentam sua aprovação depende apenas de disposição.

Antes de discutir a sugestão de proposta de reforma fiscal, os autores ainda comparam as federações e o Brasil como um todo com relação ao percentual dos impostos como proporção do PIB, a evolução das contribuições vis a vis os impostos as despesa contingenciáveis, a evolução do SUS nas transferências etc. sugerindo que efetivamente houve um aumento no papel das contribuições como fator de arrecadação e que estados e municípios também aumentaram sua participação na arrecadação total do Brasil como conseqüência da Constituinte de 1988.

A seguir, é apontado o Plano Real como um agravante do problema fiscal brasileiro. Os autores argumentam que o governo federal optou por realizar um ajuste fiscal provisório apoiado nos mesmos elementos anteriores, gerando distorções. Em particular, é apontado que a âncora cambial represaria os preços sem grandes esforços fiscais. Foram criados a IPMF (extinta CPMF), o Plano de Ação Imediata para conter os gastos subnacionais, aumento da alíquota de imposto de renda pessoa física e criação do Fundo social de Emergência (FSE). No entanto, a política fiscal teria continuado frouxa o que alimentaria o desajuste fiscal da seguinte forma: o fim da inflação elimina a receita do imposto inflacionário e estimula os governantes a conceder aumentos salariais para o funcionalismo público tendo impacto também sobre os benefícios pagos pelo INSS. Por fim, o estrago causado pela crise das contas externas associado à apreciação do câmbio e abertura da economia ajudou produzir déficits primários e elevados resultados nominais negativos não somente para o governo federal mas também para municípios e estados. Isto se deve em parte também pela alta taxa de juros praticada no país. Neste contexto, segundo os autores, o governo optou por não efetuar a reforma tributária com receio de comprometimento das receitas provocando eventuais perdas nas receitas da União. E desta forma, apontam os autores, continua a política de implementação de reformas superficiais e marginais sem grande efeito no longo prazo da situação fiscal do país. Estas políticas seriam as chamadas medidas provisórias cujos objetivos seriam orientados por urgências de curto prazo tais como alteração de alíquotas de imposto de renda e sobre o lucro, mudança de regras de dedução e isenção ainda do imposto de renda, criação da CMPF, instituição do Fundo de Estabilização Fiscal, ressarcimento da cobrança do PIS e confins sobre o setor exportador, criação do Simples, desoneração do ICMS sobre as exportações de produtos primários, aumento da alíquota do IOF, Cofins, CSLL etc. As duas únicas reformas aprovadas no período do Plano Real foram administrativa e da previdência Social, ambas com im- 
pacto pequeno em termos de resultado fiscal. Já em termos de medidas voltadas para controlar as finanças dos governos subnacionais, vale ressaltar a aprovação da Lei de Responsabilidade Fiscal e o Proes no período de 1995 a 1999. Por fim, os autores apontam que o modelo de estabilização do adotado pelo Plano Real acirrou algumas contradições no que diz respeito ao atendimento das metas do superávit primário. Em particular, é apontado o aumento da carga tributária sustentada por contribuições sociais como principal mecanismo de ajuste. Esta adoção aumentaria as distorções do sistema, o que enfraqueceria a federação.

O capítulo 3 ressalta a necessidade de implementar um ajuste nas contas públicas com vistas ao longo prazo e que leve em consideração o processo de globalização econômica enfrentado pelo país. Neste sentido, os autores apontam que bases tributárias de alta mobilidade social (trabalho qualificado, por exemplo) não devam sofrer onus elevado. Investimentos e exportações devem ser completamente desonerados. Isto atenderia preocupações quanto à competitividade, crescimento econômico e inclusão social. A pressão exercida pelo processo de globalização implica que a velocidade de implementação destas medidas seja rápida. Os autores ainda apontam que para criar condições para o federalismo fiscal implique em coesão entre os entes, a reforma deva contemplar: 1) repartição de poderes e responsabilidade entre governos, 2) defina o regime de transferências e responsabilidades e 3) execute ações para reduzir desigualdades regionais e pessoais. O livro sugere, então, uniformização dos impostos cobrados em todo país.

O livro conclui com o esqueleto de uma proposta que contempla o plano fiscal. Em particular é sugerida uma reforma abrangente, pois se argumenta que seja (ao contrário do pensamento atual) mais fácil de ser implementada. Por ser abrangente facilitaria a reforma de previdência e corte de gastos. Isto se deve ao reconhecimento de que é necessário eliminar o dualismo tributário vigente com as contribuições sociais e impostos. Estas contribuições seriam incorporadas ao capítulo tributário. Ainda deve-se conciliar a responsabilidade fiscal com a preservação de garan- tias de atendimento dos direitos sociais e que parte da solução vem do aumento da eficiência na aplicação dos recursos federais e não no montante direcionado para esses fins. O livro propõe, especificamente, medidas que seriam objetos de emenda constitucional (aqui resumidas):

1. Incorporar as contribuições sociais sobre a receita, lucro e movimentação financeira ao capítulo tributário.

2. Regular o financiamento da previdência.

3. Uniformização do ICMS.

4. Remeter a uma lei complementar a competência para instituir as garantias financeiras de atendimento dos direitos sociais coletivos (saúde, por exemplo).

Por último, acredito que o livro contribua para o entendimento do atual sistema tributário/ fiscal brasileiro e seu impacto sobre a sociedade em termos de distorções econômicas. Apesar de apresentar sobreposição de temas em seus três capítulos, os autores buscam descrever detalhadamente e com suporte de dados o quadro atual fiscal no Brasil. Estes três capítulos poderiam estar mais organizados de forma a apresentar: 1) a origem do sistema dual tributário no Brasil e sua relação com a Constituinte de 1988, 2) o Plano Real e a ausência de Plano Fiscal no período, 3) propostas de mudanças do sistema tributário e comparações baseadas em medidas adotadas por outros países em desenvolvimento.

No que diz respeito às sugestões das medidas, acredito que, apesar de estarem na direção correta, parecem também um pouco tímidas. Por exemplo, ao incorporar as contribuições sociais e a CPMF no capitulo tributário, incorpora-se também todas as distorções causadas por impostos em cascata ou ainda ao sugerir uma lei complementar para instituir garantias financeiras de atendimento dos direitos sociais coletivos parecer ser apenas uma alternativa para ganhar tempo. De qualquer forma, o livro apresenta com riqueza (impressionante) de informações o atual sistema tributário brasileiro, sua história, lições e sugestões.

Enlinson Mattos

Escola de Economia de São Paulo da Fundação Getulio Vargas 